\title{
ABCB1 Gene Is Associated With Clinical Response to SNRIs in a Local Chinese Han Population
}

\author{
Xiao-Xiao Shan ${ }^{1,2 \dagger}$, Yan Qiu ${ }^{1,2 t}$, Wei-Wei Xie ${ }^{3}$, Ren-Rong Wu ${ }^{1,2}$, Yan Yu ${ }^{4}$, Hai-Shan Wu 1,2* \\ and Le-Hua Li ${ }^{1,2 *}$

\begin{abstract}
${ }^{1}$ Department of Psychiatry, the Second Xiangya Hospital, Central South University, Changsha, China, ${ }^{2}$ Mental Health Institute of the Second Xiangya Hospital, Central South University, Chinese National Clinical Research Center on Mental Disorders, Chinese National Technology Institute on Mental Disorders, Human Key Laboratory of Psychiatry and Mental Health, Changsha, China, ${ }^{3}$ Department of Psychiatry, Ningbo Kangning Hospital, Ningbo, China, ${ }^{4}$ The People's Hospital of Hunan Province, Changsha, China
\end{abstract}

OPEN ACCESS

Edited by:

Pei Jiang,

Jining Medical University,

China

Reviewed by:

Zunnan Huang,

Guangdong Medical College,

China

Sarah Allegra, University of Turin,

Italy

${ }^{*}$ Correspondence:

Hai-Shan Wu

wuhaishan@csu.edu.cn

Le-Hua Li

lilehua@csu.edu.cn

these authors have contributed equally to this work.

Specialty section: This article was submitted to

Neuropharmacology, a section of the journal Frontiers in Pharmacology

Received: 17 August 2018 Accepted: 12 June 2019 Published: 04 July 2019

Citation:

Shan X-X, Qiu Y, Xie W-W, Wu R-R, YU Y, WU H-S and Li L-H (2019) ABCB1 Gene Is Associated With Clinical Response to SNRIs in a Local Chinese Han Population.

Front. Pharmacol. 10:761. doi: 10.3389/fphar.2019.00761
Background: The relation between the ATP-binding cassette subfamily $B$ member 1 (ABCB1) gene and major depressive disorder (MDD) has been studied in a local Chinese Han population. MDD is associated with the rs2032582 (G2677T) and rs1128503 (C12367) single-nucleotide polymorphisms (SNPs) of ABCB1 but not with rs1045642, rs2032583, rs2235040, and rs2235015. This study aims to explore the potential correlations of therapeutic responses with selective serotonin reuptake inhibitors (SSRIs) and serotoninnorepinephrine reuptake inhibitors (SNRIs) in a local Chinese Han population.

Methods: The study population included 292 patients with MDD. All patients were assessed at baseline and at first, second, fourth, and sixth weeks according to the 17-item Hamilton Rating Scale for Depression (HAM-D17) to determine their therapeutic responses to SSRIs and SNRIs.

Results: In the SSRI therapy group, the genotype or allele distribution of six SNPs was not significantly different between responders and nonresponders. In the SNRI therapy group, only rs2032583 was associated with a therapeutic response to SNRIs. The C allele of the ABCB1 rs2032583 polymorphism was negatively correlated with therapeutic responses according to logistic regression analysis.

Conclusion: The ABCB1 gene polymorphisms may not be associated with therapeutic responses to SSRIs but not with SNRIs. The TT genotype of rs2032583 could be a predictive factor of improved treatment responses to SNRIs in the Chinese population. These findings should be replicated in future studies with larger patient groups.

Keywords: $A B C B 1$ gene, clinical response, SNRIs, major depressive disorder, local Chinese Han population

\section{INTRODUCTION}

The ATP-binding cassette subfamily $B$ member 1 ( $A B C B 1)$ gene, a multidrug resistance protein 1 $(M D R 1)$ gene, is located on the chromosomal region 7q21.1 and encodes p-glycoprotein (P-gp), which plays an important role in drug bioavailability and response to drugs. P-gp is a 1280 -amino acid transporter and serves as a genetically polymorphic efflux transporter that removes foreign 
substances from cells. This protein is expressed in the bloodbrain barrier and protects the brain from drugs or neurotoxic substances, such as glucocorticoids and amyloid beta (de Klerk et al., 2013).

After treatment with regular doses of antidepressants, several patients with major depressive disorder (MDD) fail to obtain satisfactory therapeutic effects, and some patients even incur serious side effects. Among patients with MDD treated with a single antidepressant medication, only 50\% of patients received adequate clinical response, and 30\% of patients achieved recovery. There was a delayed response to symptom relief, ranging from 4 to 8 weeks. During this period, the risk of suicide increased significantly, whereas another $10 \%$ of the patients were ineffective for any kind of antidepressant medication (Weizman et al., 2012). ABCB1 gene polymorphisms affect the ability of drugs to pass through the blood-brain barrier into the central nervous system, leading to inadequate drug concentrations in the brain (Uhr et al., 2008). ABCB1 gene polymorphisms can predict the effect of antidepressant drugs that are $M D R 1$ substrates (Mihaljevic Peles et al., 2008; Sarginson et al., 2010).

Some drugs have been identified as substrates of P-gp. These drugs include nortriptyline, imipramine, escitalopram, amitriptyline, paroxetine, venlafaxine, and citalopram; and those with non- $A B C B 1$ substrates include bupropion, mirtazapine, and fluoxetine (Mihaljevic Peles et al., 2008). The $A B C B 1$ gene has single-nucleotide polymorphisms (SNPs) in the encoding regions. Variants such as C3435T (rs1045642), G2677T/A (rs2032582), and rs2032583 are the most commonly studied. Ameyaw et al. (2001) reported that $A B C B 1$ gene knockout mice possessed insufficient P-gp, leading to high drug concentrations in the blood and weak ability to eliminate drugs. The plasma concentrations of drugs in mice without the $A B C B 1$ gene were fivefold higher and seven- to 36-fold higher in the cerebrospinal fluid (Ameyaw et al., 2001).The concentrations of citalopram, venlafaxine, and d-venlafaxine in the brain of mutant mice were 3.0, 1.7, and 4.1 times higher than those in their wild-type littermates (Uhr et al., 2008). In vivo studies indicated that mdr1 ab (-/-) mutant mice possessed higher cerebral concentrations of paroxetine compared with those of mdr $1 \mathrm{ab}(+/+)$ control mice. This finding suggests that $\mathrm{P}$-gp could prevent paroxetine from entering into the brain (Uhr et al., 2003). Patients with the CC genotype of SNP rs2232583 in the $A B C B 1$ gene exhibited a higher response rate than that of patients with the TT genotype after 4 weeks of antidepressant treatment. However, in the nonP-gp substrate mirtazapine group, no difference in genotype was observed between remission and nonremission groups (Uhr et al., 2007). A similar result was also found by Sarginson et al. (2010). Moreover, Dong et al. reported that $A B C B 1$ gene polymorphisms rs4728697, rs2032583, and rs58898486 were associated with depression therapeutic response, and rs17064 was related to the curative effect of desipramine (Dong et al., 2009). ABCB1 haplotypes and SNPs rs1045642, rs2032582, and rs2032583 affect responses to antidepressant treatment (Menu et al., 2010; Rosenhagen and Uhr, 2011; Lin et al., 2011; Singh et al., 2012; de Klerk et al., 2013).
A total of 292 Chinese patients with MDD and 208 unrelated control individuals from a local Chinese Han population were studied. There are few studies on the relationship between gene polymorphism of $A B C B 1$ and depression in the Chinese Han population; only a team of Taiwan scholars studied the relationship between the efficacy of escitalopram and gene polymorphism of $A B C B 1$ in patients with depression (Lin et al., 2011). The purpose of this study was to further understand the relationship between the two in the Chinese Han population and to provide a theoretical basis for individualized treatment.

\section{MATERIALS AND METHODS}

\section{Subjects}

A total of 292 patients with MDD and 208 healthy controls were included in this study. All participants were biologically unrelated and of Chinese Han ethnicity. The patients were diagnosed as having MDD as defined in the Axis I of the Diagnostic and Statistical Manual of Mental Disorders, Fourth Edition, Text Revision (DSM-IV-TR) and obtained scores $\geq 18$ by the 17-item Hamilton Depression (HAM-D17) Rating Scale. A consensus diagnosis by at least two psychiatrists was made for each patient according to the DSM-IV criteria. Patients were not eligible to participate in the study if they have any other mental disorder according to DSM-IV-TR Axis I criteria, had major physical and neurological illnesses and sequelae of serious illness, or serious suicide attempts and behavior. Patients were also excluded if they had used electroconvulsive therapy or antipsychotic drugs with long-lasting effects within the last 6 months or any antipsychotic drugs within the last 4 weeks. The mean ages \pm standard deviations of the patients and controls were $30.89 \pm 10.92$ years and $31.71 \pm 8.25$ years, respectively. Among the 292 patients with MDD, 71.6\% had a single episode and $28.4 \%$ had recurrent episodes. The study protocol was approved by the Medical Ethics Committee of Second Xiangya Hospital, Central South University. Written informed consent was obtained from each patient after the study was explained.

\section{Study Design}

Eligible patients were treated with one of the five antidepressants (escitalopram, paroxetine, sertraline, duloxetine, and venlafaxine) for 6 weeks. All patients affirmed a regular dose intake of antidepressant drug per day during the study. The primary efficacy measurement was the change in the HAM-D17 total score from baseline until the end of the study period. Patients were evaluated at screening, baseline, and on the first, second, fourth, and sixth weeks of treatment. Response was defined as changes in the HAM-D17 total score of $\geq 50 \%$.

\section{Sample Collection and DNA Extraction}

Peripheral blood samples were collected from ethylene diamine tetraacetic acid (EDTA)-containing tubes following the standard venipuncture technique. Genomic DNA was extracted from whole blood according to standard procedures. In this study, 
we selected SNPs by the following three methods: literature reviewing, searching for Tag-SNP, and searching for functional variant sites by FAST SNP. Finally, we investigated the following six SNPs of the $A B C B 1$ gene: SNP1 (rs1045642) in exon 27, SNP2 (rs2032583) in intron 22, SNP3 (rs2032582) in exon 22, SNP4 (rs2235040) in intron boundary exon 21, SNP5 (rs1128503) in exon 13, and SNP6 (rs2235015) in intron 5 of the $A B C B 1$ gene. All genotyping experiments were carried out by Shanghai BioWing Applied Biotechnology Company (http://www.biowing.com.cn). The AxyPrep Blood Genomic DNA Kit was used for extraction, and the ligase detection reaction (LDR) was used to detect the six SNPs. The LDR was performed in 30 cycles at $95^{\circ} \mathrm{C}$ for $2 \mathrm{~min}$, $94^{\circ} \mathrm{C}$ for $15 \mathrm{~s}$, and $50^{\circ} \mathrm{C}$ for $25 \mathrm{~s}$. Target DNA sequences were amplified using a multiplex polymerase chain reaction method. The fluorescent products of the LDR were differentiated using a $3730 \mathrm{ABI}$ sequencer.

\section{Haplotype and Statistical Analysis}

Two independent sample $t$-test and $\chi^{2}$ test were used to examine the clinical and demographic variables between responders and nonresponders. Genotype and allele frequency distributions were compared between the patients and controls and between the responders and nonresponders using the $\chi^{2}$ test for independence. The observed genotype frequencies were compared with the predicted frequencies to investigate the concordance with the Hardy-Weinberg (H-W) equilibrium. Logistic regression analysis was used to estimate the therapeutic effect associated with each genotype; odds ratios with 95\% confidence intervals were obtained. A $p<0.05$ was considered to be statistically significant. The SHEsis online analysis software was used for linkage disequilibrium and haplotype analysis. Logistic regression analyses were performed using Statistical Package for the Social Sciences version 17.0 for Windows software (SPSS Inc., Chicago, IL). Adjustment for multiple comparisons was performed by Bonferroni correction.

\section{RESULTS}

\section{Comparison of General Data Between Control and Case Groups}

A total of 208 cases in the control group, 101 males and 107 females, the average age was $31.71 \pm 8.25$ years. There were 292 patients in the study group, 143 males and 149 females; the average age was $30.89 \pm 10.92$ years. There was no significant difference in gender and age composition between the control group and the case group $\left(\chi^{2}=0.008, p=0.927 ; t=0.954, p=\right.$ $0.341)$, which was comparable.

\section{Hardy-Weinberg Balance Analysis of $A B C B 1$ Gene Polymorphisms in the Control and Case Groups}

Among the 208 control subjects, the theoretical number of genotypes was 81 , the number of genotypes of CT was 98 , and the number of genotypes of TT was 29 . H-W analysis showed that there was no significant difference in the actual genotype distribution of rsl045642 SNP and the theoretical gene type distribution under H-W equilibrium, $\chi^{2}=1.231, p=0.267$. According to this method, the H-W balance test was performed on the polymorphic loci rsl045642, rs2032583, rs2032582, rs2235040, rsl128503, and rs2235015 between the control group and the case group. As shown in Table 1, the six SNPs loci in the control and case groups all met the $\mathrm{H}-\mathrm{W}$ balance. The population selected in this study is representative of the Han population and suitable for genetic analysis.

\section{Comparison of Clinical Features Among the Responders and Nonresponders}

Among the 292 patients included in this study, 39 patients dropped out because of adverse effects $(n=12)$, withdrawal of consent $(n=9)$, contrary to the scheme $(n=2)$, and lost to

TABLE 1 | Equilibrium test of six single-nucleotide polymorphisms (SNPs) between the control group and the case group.

\begin{tabular}{|c|c|c|c|c|c|c|c|c|c|}
\hline \multirow[t]{2}{*}{ SNP } & \multirow[t]{2}{*}{ Genotype } & \multicolumn{4}{|c|}{ Controls $(n=208)$} & \multicolumn{4}{|c|}{ Cases $(n=292)$} \\
\hline & & $\begin{array}{l}\text { Actual } \\
\text { number }\end{array}$ & $\begin{array}{c}\text { Theoretical } \\
\text { number }\end{array}$ & $\chi^{2}$ & $\mathbf{p}$ & $\begin{array}{l}\text { Actual } \\
\text { number }\end{array}$ & $\begin{array}{c}\text { Theoretical } \\
\text { number }\end{array}$ & $\chi^{2}$ & $\mathbf{p}$ \\
\hline \multirow[t]{3}{*}{ rs1045642 } & $\mathrm{CC}$ & 85 & 81 & 1.23 & 0.267 & 103 & 109 & 2.27 & 0.132 \\
\hline & CT & 90 & 98 & & & 151 & 139 & & \\
\hline & $\pi$ & 33 & 29 & & & 38 & 44 & & \\
\hline \multirow[t]{2}{*}{ rs2032583 } & CT & 22 & 21 & 0.65 & 0.42 & 38 & 37 & 1.41 & 0.234 \\
\hline & $\pi$ & 186 & 187 & & & 254 & 255 & & \\
\hline \multirow[t]{3}{*}{ rs2032582 } & GG & 78 & 72 & 3.39 & 0.065 & 86 & 78 & 3.44 & 0.06 \\
\hline & GT & 88 & 101 & & & 130 & 146 & & \\
\hline & $\pi$ & 42 & 36 & & & 76 & 68 & & \\
\hline \multirow[t]{2}{*}{ rs2235040 } & $A G$ & 22 & 21 & 0.65 & 0.42 & 40 & 38 & 1.58 & 0.21 \\
\hline & GG & 186 & 187 & & & 252 & 254 & & \\
\hline \multirow[t]{3}{*}{ rs1128503 } & $\mathrm{CC}$ & 39 & 34 & 1.8 & 0.18 & 40 & 35 & 1.97 & 0.161 \\
\hline & CT & 91 & 100 & & & 121 & 132 & & \\
\hline & $\Pi$ & 78 & 73 & & & 131 & 126 & & \\
\hline \multirow[t]{2}{*}{ rs2235015 } & GG & 187 & 188 & 0.59 & 0.44 & 254 & 255 & 1.414 & 0.23 \\
\hline & GT & 21 & 20 & & & 38 & 37 & & \\
\hline
\end{tabular}


follow-up ( $n=16$ ); lastly, 253 patients completed the study. Clinical characteristics, use of drugs, and average drug doses between responders and nonresponders are shown in Table 2. No significant differences were found between the two groups according to the above indicators.

\section{Genotype and Allele Frequencies in the Responders and Nonresponders}

Genotype and allele distributions for the examined $A B C B 1$ gene SNPs in nonresponders and responders are shown in Table 3. The genotype and allelic distributions of rs1045642, rs2032582, rs2235040, rs1128503, and rs2235015 SNPs were not significantly different between nonresponders and responders. For rs2032583, genotype and allelic distributions significantly differed between the nonresponders and responders. The distribution of TT genotype and $\mathrm{T}$ allele frequency was higher in the responders than that in the nonresponders ( $p=0.027, p=0.033$, respectively).

\section{$A B C B 1$ Gene Polymorphism Loci and Clinical Response to Selective Serotonin Reuptake Inhibitors}

For SSRIs (sertraline, paroxetine, and escitalopram), no significant difference in genotype and allele frequency distribution was observed between the responders and nonresponders $(p>0.05)$ (Table 4).

The efficacy of SSRIs was examined for genotypes in the SSRI treatment group according to the HAM-D17 scores, decreased scores, and reducing score rate during the first, second, fourth, and sixth weeks. The HAM-D17 scores, decreased scores, and reducing score rate at the first, second, fourth, and sixth weeks were not significantly different among rs1045642, rs2032583, rs2032582, rs1128503, and rs2235015 ( $p>0.05)$. HAM-D17 decreased scores and reducing score rate did not reveal any significant difference with rs2235040 (Table 5); however, a significant difference was observed for the genotype of rs2235040 in the HAM-D17 scores $(\mathrm{F}=4.349, p=0.039)$ (Figure 1).

\section{ABCB1 Gene Polymorphism Loci and Clinical Response to Serotonin- Norepinephrine Reuptake Inhibitors}

For SNRIs (venlafaxine and duloxetine), no significant difference was observed in the distribution of genotype and allele frequency of the rs1045642, rs2032582, rs2235040, rs1128503, and rs2235015 SNPs between the responders and nonresponders $(p>0.05)$. For rs2032583, the T allele frequency and TT genotype were significantly increased in the responders compared with those in the nonresponders ( $p=0.025$ and $p=0.018$, respectively) (Table 6).

For SNRIs (venlafaxine and duloxetine), no significant difference was observed for the rs1045642, rs2032582, and rs1128503 SNPs in any of the HAM-D17 scores, decreased scores, and reducing score rate during the first, second, fourth, and sixth weeks $(p>0.05)$. For rs2032583, the HAM-D17 scores of TT genotype are lower than those of the CT genotype, whereas the decreased scores and reducing score rate are higher than those of the CT genotype (Table 7 and Figure 2). The GG genotypes of rs2235040 have lower HAM-D17 scores than AG genotypes and higher decreased score and reducing score rate than AG genotypes (Table 8 and Figure 3). For rs2235015, the GG genotypes have lower HAM-D17 scores than those of the GT genotypes and higher in decreased score and reducing score rate than those of the GT genotypes (Table 9 and Figure 4).

\section{DISCUSSION}

We investigated the association among the six SNPs of the $A B C B 1$ gene and therapeutic response in the local Chinese Han population. Among the five SNPs, only one SNP (rs2032583)

TABLE 2 | Clinical features, dosage, and drug among the responders and the nonresponders.

\begin{tabular}{|c|c|c|c|c|c|}
\hline & & $\begin{array}{c}\text { Nonresponders } \\
\quad(n=54)\end{array}$ & $\begin{array}{c}\text { Responders } \\
(n=199)\end{array}$ & $\mathbf{F}$ & $p$ \\
\hline Age (years) & & $31.19 \pm 10.124$ & $30.78 \pm 11.484$ & 1.089 & 0.298 \\
\hline Education & & $12.17 \pm 3.994$ & $11.93 \pm 3.968$ & 0.274 & 0.601 \\
\hline \multirow[t]{2}{*}{ Sex } & Male $n(\%)$ & $27(50)$ & 98(49.2) & 0.012 & 0.912 \\
\hline & Female $n(\%)$ & $27(50)$ & $101(50.8)$ & & \\
\hline \multirow{2}{*}{ Marriage } & Divorced $n(\%)$ & $3(5.6)$ & $8(4.0)$ & & \\
\hline & Remarriage $n(\%)$ & $1(1.9)$ & $\mathrm{O}(0.0)$ & & \\
\hline \multirow[t]{5}{*}{ Drug } & Escitalopram n (\%) & 19(35.2) & $67(33.7)$ & 5.713 & \\
\hline & Paroxetine $n(\%)$ & $6(11.1)$ & $44(22.1)$ & & \\
\hline & Venlafaxine $n(\%)$ & 19(35.2) & $46(23.1)$ & & 0.222 \\
\hline & Duloxetine $n(\%)$ & $7(13.0)$ & $34(17.1)$ & & \\
\hline & Sertraline $n(\%)$ & $3(5.6)$ & $8(4.0)$ & & \\
\hline Doses & Sertraline & $58.33 \pm 14.434$ & $105.63 \pm 52.470$ & & \\
\hline
\end{tabular}


TABLE 3 | Genotype and allele frequencies of six SNPs of the ABCB1 gene in the nonresponders and the responders.

\begin{tabular}{|c|c|c|c|c|c|c|c|c|}
\hline \multirow{2}{*}{$\begin{array}{l}\text { Genotype/ } \\
\text { allele } \\
\text { rs1045642 }\end{array}$} & \multirow{2}{*}{$\begin{array}{l}\text { Responders } \\
(n=199)(\%)\end{array}$} & \multirow{2}{*}{$\begin{array}{c}\text { Nonresponders } \\
(\mathrm{n}=54)(\%)\end{array}$} & \multirow[t]{2}{*}{$\chi^{2}$} & \multirow[t]{2}{*}{$p$} & \multicolumn{2}{|c|}{ OR $(95 \% \mathrm{Cl})$} & \multicolumn{2}{|c|}{ Adjust OR (95\% Cl) } \\
\hline & & & & & & & & \\
\hline $\mathrm{CC}$ & 73 (36.7) & 21 (38.9) & & & 1 & & 1 & \\
\hline CT & $97(48.7)$ & $26(48.1)$ & 0.136 & 0.934 & 1.073 & $0.560-2.056$ & 1.159 & $0.575-2.336$ \\
\hline$\pi$ & 29 (14.6) & 7 (13.0) & & & 1.192 & $0.457-3.105$ & 0.826 & $0.301-2.270$ \\
\hline C allele & $243(61.1)$ & 68 (63.0) & & & 1 & & 1 & \\
\hline T allele & 155 (38.9) & $40(37.0)$ & 0.131 & 0.718 & 1.084 & $0.699-1.683$ & 0.762 & 0.299-1.945 \\
\hline \multicolumn{9}{|l|}{ rs2032583 } \\
\hline$\pi$ & $175(87.9)$ & 41 (75.9) & & & 1 & & 1 & \\
\hline CT & $24(12.1)$ & $13(24.1)$ & 4.91 & $0.027^{\star}$ & $0.433^{\star}$ & $0.203-0.921$ & $0.4^{\star}$ & $0.179-0.896$ \\
\hline T allele & $374(94.0)$ & 95 (88.0) & & & 1 & & 1 & \\
\hline C allele & $24(6.0)$ & $13(12.0)$ & 4.52 & $0.033^{*}$ & $0.469^{\star}$ & $0.23-0.955$ & $0.4^{\star}$ & $0.179-0.8966$ \\
\hline \multicolumn{9}{|l|}{ rs2032582 } \\
\hline $\mathrm{GG}$ & 63 (31.7) & 16 (29.6) & & & 1 & & 1 & \\
\hline GT & $81(40.7)$ & 25 (46.3) & 0.574 & 0.751 & 0.823 & $0.405-1.671$ & 0.878 & $0.41-1.877$ \\
\hline$\pi$ & 55 (27.6) & $13(24.1)$ & & & 1.074 & $0.475-2.431$ & 0.917 & $0.386-2.178$ \\
\hline G allele & 207 (52.0) & 57 (52.8) & & & 1 & & 1 & \\
\hline T allele & 191 (48.0) & $51(47.2)$ & 0.02 & 0.887 & 1.031 & $0.674-1.579$ & 0.989 & 0.473-2.07 \\
\hline \multicolumn{9}{|l|}{ rs2235040 } \\
\hline$A G$ & 27 (13.6) & 12 (22.2) & & & 1 & & 1 & \\
\hline GG & 172 (86.4) & $42(77.8)$ & 2.44 & 0.118 & 1.82 & $0.852-3.888$ & 2.031 & $0.905-4.558$ \\
\hline A allele & $27(6.8)$ & $12(11.1)$ & & & 1 & & 1 & \\
\hline G allele & 371 (93.2) & $96(88.9)$ & 2.236 & 0.135 & 1.718 & $0.839-3.515$ & 2.047 & $0.919-4.56$ \\
\hline \multicolumn{9}{|l|}{ rs1128503 } \\
\hline $\mathrm{CC}$ & 26 (13.1) & $8(14.8)$ & & & 1 & & 1 & \\
\hline CT & 79 (39.7) & 27 (50.0) & 2.554 & 0.279 & 0.9 & $0.364-2.225$ & 0.905 & $0.348-2.352$ \\
\hline C allele & $131(32.9)$ & $43(39.8)$ & & & 1 & & 1 & \\
\hline T allele & $267(67.1)$ & $65(60.2)$ & 1.793 & 0.181 & 1.348 & $0.87-2.09$ & 1.41 & $0.727-2.734$ \\
\hline \multicolumn{9}{|l|}{ rs2235015 } \\
\hline GG & $174(87.4)$ & $42(77.8)$ & & & 1 & & 1 & \\
\hline GT & 25 (12.6) & 12 (22.2) & 3.174 & 0.075 & 0.503 & $0.234-1.082$ & 0.416 & $0.204-1.04$ \\
\hline G allele & $373(93.7)$ & 96 (88.9) & & & 1 & & 1 & \\
\hline T allele & 25 (6.3) & $12(11.1)$ & 2.924 & 0.087 & 0.536 & $0.26-1.108$ & 0.530 & $0.21-1.01$ \\
\hline
\end{tabular}

*Statistically significant difference between the groups $(p<0.05)$.

$\mathrm{Cl}$, confidence interval; OR, odds ratio.

differed in genotype and allele frequencies between the responders and nonresponders. In particular, the TT genotype of this SNP was significantly more common in the responders than that in the nonresponders. This finding suggests that the C allele of rs2032583 may be a risk factor for MDD. In the SSRI therapy group, no correlation was found between the six SNPs of the $A B C B$ 1gene and therapeutic response to SSRIs $(p>0.05)$. However, for the SNRI therapy group, only rs2032583 is associated with a therapeutic response to SNRIs in patients with MDD. The $\mathrm{C}$ allele of the $A B C B$ 1 gene SNP rs2032583 was negatively correlated with therapeutic response according to the logistic regression analyses. The genotype of $A B C B 1$ gene SNPs rs2235015 and rs2235040 were associated with decreased score and reducing score rate in the SNRIs therapy group, but because of the small sample size, there was no significant difference in the final effective and ineffective grouping. This finding indicated that $A B C B 1$ gene polymorphisms may not be associated with the treatment response to SSRIs, but with SNRIs. The TT genotype of the $A B C B 1$ gene SNP rs2032583 could be a predictive factor of improved treatment response to SNRIs. To our knowledge, this study is the first to report the genetic association of
$A B C B 1$ gene polymorphism with therapeutic responses in a casecontrol design in Chinese Han people in Mainland China.

P-gp can restrict the entry of various substrates, such as antidepressants, from the bloodstream into the brain. Studies on $A B C B 1$ knockout animals have shown that $A B C B 1-/-$ mice possess higher intracerebral concentrations of escitalopram, trimipramine, amitriptyline, doxepin, venlafaxine, and paroxetine compared with those in wild-type mice (Uhr et al., 2000; Uhr et al., 2002; Uhr et al., 2003). Kato et al. (2008) reported a significant association of the nonsynonymous SNP G2677T/A (rs2032582) with treatment response to paroxetine in depressed patients. Moreover, the wild variant haplotype $3435 C-2677 G-1236 \mathrm{~T}$ is associated with poor response (Kato et al., 2008). In contrast, Nikisch et al. (2008) found that depressed patients harboring the 2677 GG/GT genotype responded to escitalopram treatment significantly better than patients with the 2677TT genotype and suggested that this polymorphism could be used as genetic markers for predicting treatment response to escitalopram treatment in $\mathrm{MDD}(n=15)$. Uhr et al. (2008) showed that polymorphisms in the $A B C B 1$ gene predict the response to antidepressant treatment in depressed patients $(n=133)$ receiving 
TABLE 4 | Genotype, allelic distribution of all genotyped single nucleotide polymorphisms among the treatment responders and nonresponders for selective serotonin reuptake inhibitor (SSRI) drugs group.

\begin{tabular}{|c|c|c|c|c|c|c|}
\hline & $\begin{array}{l}\text { Responders } \\
(n=119)(\%)\end{array}$ & $\begin{array}{c}\text { Nonresponders } \\
(n=28)(\%)\end{array}$ & $\chi^{2}$ & $p$ & OR (95\% Cl) & Adjust OR $(95 \% \mathrm{Cl})$ \\
\hline \multicolumn{7}{|l|}{ rs1045642 } \\
\hline $\begin{array}{l}\text { CC } \\
\text { CT } \\
\text { TT } \\
\text { C allele } \\
\text { T allele }\end{array}$ & $\begin{array}{l}42(35.3) \\
60(50.4) \\
17(14.3) \\
144(60.5) \\
94(39.5)\end{array}$ & $\begin{array}{c}9(32.1) \\
14(50.0) \\
5(17.9) \\
32(57.1) \\
24(42.9)\end{array}$ & $\begin{array}{l}0.259 \\
0.213\end{array}$ & $\begin{array}{l}0.879 \\
0.644\end{array}$ & $\begin{array}{c}1 \\
0.918(0.364-2.317) \\
0.729(0.213-2.492) \\
1 \\
0.87(0.483-1.57)\end{array}$ & $\begin{array}{c}1 \\
0.717(0.255-2.02) \\
0.389(0.098-1.551) \\
1 \\
0.479(0.143-1.601)\end{array}$ \\
\hline \multicolumn{7}{|l|}{ rs2032583 } \\
\hline $\begin{array}{l}\text { Tा } \\
\text { CT } \\
\text { T allele } \\
\text { C allele }\end{array}$ & $\begin{array}{c}106(89.1) \\
13(10.9) \\
225(94.5) \\
13(5.5)\end{array}$ & $\begin{array}{c}24(85.7) \\
4(14.3) \\
52(92.9) \\
4(7.1)\end{array}$ & $\begin{array}{l}0.25 \\
0.235\end{array}$ & $\begin{array}{l}0.617 \\
0.628\end{array}$ & $\begin{array}{c}1 \\
0.736(0.221-2.455) \\
1 \\
0.751(0.235-2.397)\end{array}$ & $\begin{array}{c}1 \\
0.751(0.205-2.747) \\
1 \\
0.751(0.205-2.747)\end{array}$ \\
\hline \multicolumn{7}{|l|}{ rs2032582 } \\
\hline $\begin{array}{l}\text { GG } \\
\text { GT } \\
\text { TT } \\
\text { G allele } \\
\text { T allele }\end{array}$ & $\begin{array}{c}38(31.9) \\
53(44.5) \\
28(23.5) \\
129(54.2) \\
109(45.8)\end{array}$ & $\begin{array}{c}5(17.9) \\
14(50.0) \\
9(32.1) \\
24(42.9) \\
32(57.1)\end{array}$ & $\begin{array}{l}2.352 \\
2.338\end{array}$ & $\begin{array}{l}0.309 \\
0.126\end{array}$ & $\begin{array}{c}1 \\
0.498(0.165-1.501) \\
0.409(0.124-1.355) \\
1 \\
0.634(0.352-1.14)\end{array}$ & $\begin{array}{c}1 \\
0.336(0.09-1.256) \\
0.237(0.057-0.984) \\
1 \\
0.509(0.189-1.37)\end{array}$ \\
\hline \multicolumn{7}{|c|}{ rs2235040 } \\
\hline $\begin{array}{l}\text { AG } \\
\text { GG } \\
\text { A allele } \\
\text { G allele }\end{array}$ & $\begin{array}{c}15(12.6) \\
104(87.4) \\
15(6.3) \\
223(93.7)\end{array}$ & $\begin{array}{c}4(14.3) \\
24(85.7) \\
4(7.1) \\
52(92.9)\end{array}$ & $\begin{array}{l}0.056 \\
0.052\end{array}$ & $\begin{array}{l}0.813 \\
0.82\end{array}$ & $\begin{array}{c}1 \\
1.156(0.352-3.794) \\
1 \\
1.144(0.364-3.588)\end{array}$ & $\begin{array}{c}1 \\
1.129(0.316-4.032) \\
1 \\
1.129(0.316-4.032)\end{array}$ \\
\hline \multicolumn{7}{|c|}{ rs1128503 } \\
\hline $\begin{array}{l}\text { CC } \\
\text { CT } \\
\text { TT } \\
\text { C allele } \\
\text { T allele }\end{array}$ & $\begin{array}{c}16(13.4) \\
39(32.8) \\
64(53.8) \\
71(29.8) \\
167(70.2)\end{array}$ & $\begin{array}{c}2(7.1) \\
14(50.0) \\
12(42.9) \\
18(32.1) \\
38(67.9)\end{array}$ & $\begin{array}{l}3.124 \\
0.115\end{array}$ & $\begin{array}{l}0.21 \\
0.735\end{array}$ & $\begin{array}{c}1 \\
0.348(0.071-1.711) \\
0.667(0.135-3.282) \\
1 \\
1.114(0.596-2.083)\end{array}$ & $\begin{array}{c}1 \\
0.303(0.057-1.627) \\
0.483(0.091-2.57) \\
1 \\
1.224(0.494-3.033)\end{array}$ \\
\hline \multicolumn{7}{|c|}{ rs2235015 } \\
\hline $\begin{array}{l}\text { GG } \\
\text { GT } \\
\text { G allele } \\
\text { T allele }\end{array}$ & $\begin{array}{c}106(89.1) \\
13(10.9) \\
225(94.6) \\
13(5.5)\end{array}$ & $\begin{array}{c}24(85.7) \\
4(14.3) \\
52(92.9) \\
4(7.1)\end{array}$ & $\begin{array}{c}0.25 \\
0.235\end{array}$ & $\begin{array}{l}0.617 \\
0.628\end{array}$ & $\begin{array}{c}1 \\
0.736(0.221-2.455) \\
1 \\
0.751(0.235-2.397)\end{array}$ & $\begin{array}{c}1 \\
0.696(0.191-2.543) \\
1 \\
0.751(0.235-2.397)\end{array}$ \\
\hline
\end{tabular}

TABLE 5 | Rs2235040 and response to antidepressants.

\begin{tabular}{|c|c|c|c|c|c|c|c|}
\hline & & 1 week & 2 weeks & 4 weeks & 6 weeks & $\mathbf{F}$ & $\mathbf{p}$ \\
\hline \multirow[t]{2}{*}{ Decreased score } & $\mathrm{AG}(n=19)$ & $1.42 \pm 1.71$ & $5.47 \pm 5.28$ & $12.47 \pm 5.78$ & $17.42 \pm 5.27$ & 0.147 & 0.702 \\
\hline & $\mathrm{GG}(n=128)$ & $1.93 \pm 2.49$ & $5.74 \pm 4.57$ & $11.75 \pm 5.99$ & $15.82 \pm 6.37$ & & \\
\hline \multirow{2}{*}{$\begin{array}{l}\text { Reducing score } \\
\text { rate (\%) }\end{array}$} & $\mathrm{AG}(n=19)$ & $5.31 \pm 6.43$ & $20.74 \pm 18.96$ & $47.36 \pm 19.63$ & $67.3 \pm 17.42$ & 0.323 & 0.571 \\
\hline & $\mathrm{GG}(n=128)$ & $8.38 \pm 11.31$ & $24.50 \pm 19.09$ & $49.64 \pm 22.97$ & $67.04 \pm 23.77$ & & \\
\hline
\end{tabular}

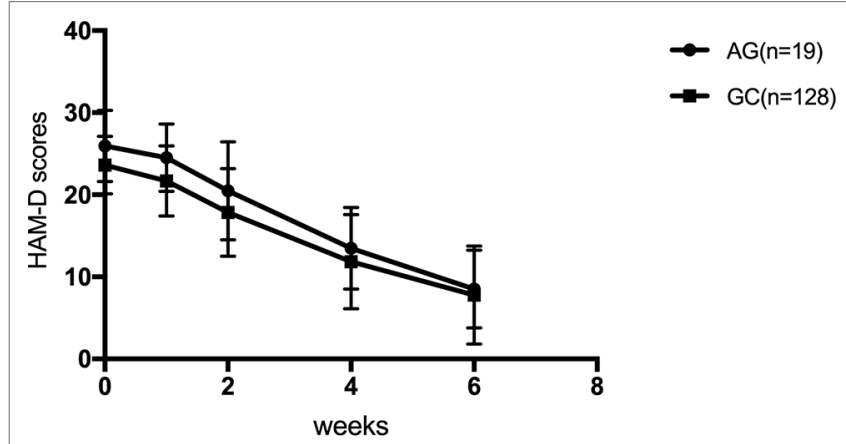

FIGURE 1 | Hamilton Rating Scale for Depression (HAM-D) scores at the first, second, fourth, and sixth week. drugs that have been identified as substrates of P-gp (amitriptyline, paroxetine, venlafaxine, and escitalopram). However, Mihaljevic et al. (2008) found that MDR1 variants G2677T (rs2032582) and C3435T (rs1045642) are not associated with therapeutic response to paroxetine in patients with $\operatorname{MDD}(n=127)$. Furthermore, Peters et al. (2008) did not find an association between $A B C B 1 C 3435 T$, G2677T, and C1236T polymorphisms and response and tolerance to citalopram in a large study sample $(n=831)$.

$A B C B 1$ gene polymorphism loci mutation might cause the variation of $\mathrm{P}$-gp, thereby increasing drug concentrations in the brain to improve therapeutic effects. The specific function of rs2032583 (intron 22) is not clear. Clinical research has found the association between rs2032583 and antidepressant effects. The wild-type allele of rs 2032583 is $\mathrm{T}$ and the mutant allele is C. 
TABLE 6 | Genotype, allelic distribution of all genotyped SNPs among the treatment responders and nonresponders for serotonin-norepinephrine reuptake inhibitors (SNRIS).

\begin{tabular}{|c|c|c|c|c|c|c|}
\hline & $\begin{array}{c}\text { Responders } \\
(n=80)(\%)\end{array}$ & $\begin{array}{c}\text { Nonresponders } \\
(n=26)(\%)\end{array}$ & $\mathbf{X}^{2}$ & $p$ & OR (95\% Cl) & Adjust OR $(95 \% \mathrm{Cl})$ \\
\hline \multicolumn{7}{|l|}{ rs1045642 } \\
\hline $\begin{array}{l}\text { CC } \\
\text { CT } \\
\text { TT } \\
\text { C allele } \\
\text { T allele }\end{array}$ & $\begin{array}{l}31(38.8) \\
37(46.3) \\
12(15.0) \\
99(61.9) \\
61(38.1)\end{array}$ & $\begin{aligned} 12 & (46.2) \\
12 & (46.2) \\
2 & (7.7) \\
36 & (69.2) \\
16 & (30.8)\end{aligned}$ & $\begin{array}{l}1.059 \\
0.918\end{array}$ & $\begin{array}{l}0.589 \\
0.338\end{array}$ & $\begin{array}{c}1 \\
1.194(0.47-3.03) \\
2.323(0.451-11.96) \\
1 \\
1.386(0.71-2.709)\end{array}$ & $\begin{array}{c}1 \\
1.898(0.644-5.593) \\
1.499(0.263-8.537) \\
1 \\
1.11(0.208-5.932)\end{array}$ \\
\hline \multicolumn{7}{|c|}{ rS2032583 } \\
\hline $\begin{array}{l}\text { TT } \\
\text { CT } \\
\text { T allele } \\
\text { C allele }\end{array}$ & $\begin{array}{c}69(86.3) \\
11(13.8) \\
149(93.1) \\
11(6.9)\end{array}$ & $\begin{array}{l}17(65.4) \\
9(34.6) \\
43(82.7) \\
9(17.3)\end{array}$ & $\begin{array}{l}5.581 \\
4.999\end{array}$ & $\begin{array}{l}0.018^{\star} \\
0.025^{\star}\end{array}$ & $\begin{array}{c}1 \\
0.301^{*}(0.108-0.842) \\
0.353^{*}(0.137-0.907)\end{array}$ & 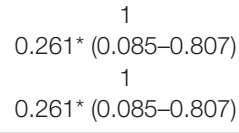 \\
\hline \multicolumn{7}{|l|}{ rs2032582 } \\
\hline $\begin{array}{l}\text { GG } \\
\text { GT } \\
\text { TT } \\
\text { G allele } \\
\text { T allele }\end{array}$ & $\begin{array}{c}25(31.3) \\
28(35) \\
27(33.8) \\
78(48.75) \\
82(51.25)\end{array}$ & $\begin{array}{l}11(42.3) \\
11(42.3) \\
4(15.4) \\
33(63.5) \\
19(36.5)\end{array}$ & $\begin{array}{l}3.254 \\
3.405\end{array}$ & $\begin{array}{l}0.196 \\
0.065\end{array}$ & $\begin{array}{c}1 \\
1.12(0.414-3.028) \\
2.97(0.836-10.55) \\
1 \\
1.826(0.959-3.477)\end{array}$ & $\begin{array}{c}1 \\
1.466(0.473-4.541) \\
2.502(0.644-9.72) \\
1 \\
2.07(0.598-7.170)\end{array}$ \\
\hline \multicolumn{7}{|l|}{ rs2235040 } \\
\hline $\begin{array}{l}\text { AG } \\
\text { GG } \\
\text { A allele } \\
\text { G allele }\end{array}$ & $\begin{array}{c}12(15) \\
68(85) \\
12(7.5) \\
148(92.5)\end{array}$ & $\begin{array}{c}8(30.8) \\
18(69.2) \\
8(15.4) \\
44(84.6)\end{array}$ & $\begin{array}{l}3.188 \\
2.856\end{array}$ & $\begin{array}{l}0.074 \\
0.091\end{array}$ & $\begin{array}{c}1 \\
2.519(0.895-7.086) \\
1 \\
2.242(0.862-5.832)\end{array}$ & $\begin{array}{c}1 \\
2.98(0.96-9.245) \\
1 \\
2.98(0.96-9.245)\end{array}$ \\
\hline \multicolumn{7}{|l|}{ rs1128503 } \\
\hline $\begin{array}{l}\text { CC } \\
\text { CT } \\
\text { TT } \\
\text { C allele } \\
\text { T allele }\end{array}$ & $\begin{array}{c}10(12.5) \\
40(50.0) \\
30(37.5) \\
60(37.5) \\
100(62.5)\end{array}$ & $\begin{array}{c}6(23.1) \\
13(50.0) \\
7(26.9) \\
25(48.1) \\
27(51.9)\end{array}$ & $\begin{array}{l}2.083 \\
1.828\end{array}$ & $\begin{array}{l}0.353 \\
0.176\end{array}$ & $\begin{array}{c}1 \\
1.846(0.562-6.068) \\
2.571(0.698-9.476) \\
1 \\
1.543(0.821-2.901)\end{array}$ & $\begin{array}{c}1 \\
1.838(0.495-6.818) \\
1.819(0.422-7.839) \\
1 \\
1.149(0.385-3.43)\end{array}$ \\
\hline \multicolumn{7}{|l|}{ rs2235015 } \\
\hline $\begin{array}{l}\text { GG } \\
\text { GT } \\
\text { G allele } \\
\text { T allele }\end{array}$ & $\begin{array}{c}68(85.0) \\
12(15.0) \\
148(92.5) \\
12(7.5)\end{array}$ & $\begin{array}{l}18(69.2) \\
8(30.8) \\
44(84.6) \\
8(15.4)\end{array}$ & $\begin{array}{l}3.188 \\
2.856\end{array}$ & $\begin{array}{l}0.074 \\
0.091\end{array}$ & $\begin{array}{c}1 \\
0.397(0.141-1.117) \\
1 \\
0.446(0.171-1.16)\end{array}$ & $\begin{array}{c}1 \\
0.983(0.944-1.024) \\
1 \\
0.446(0.171-1.16)\end{array}$ \\
\hline
\end{tabular}

*Statistically significant difference between the groups $(p<0.05)$.

TABLE 7 | Rs2032583 and response to antidepressants.

\begin{tabular}{|c|c|c|c|c|c|c|c|}
\hline & & 1 week & 2 weeks & 4 weeks & 6 weeks & $\mathbf{F}$ & $p$ \\
\hline \multirow[t]{2}{*}{ Decreased score } & $\mathrm{CT}(n=17)$ & $1.40 \pm 1.79$ & $4.60 \pm 4.11$ & $10.3 \pm 6.33$ & $13.1 \pm 6.51$ & 5.949 & $0.016^{\star}$ \\
\hline & $\Pi(n=130)$ & $2.23 \pm 2.67$ & $7.33 \pm 4.62$ & $12.86 \pm 5.28$ & $16.36 \pm 5.29$ & & \\
\hline \multirow{2}{*}{$\begin{array}{l}\text { Reducing score } \\
\text { rate (\%) }\end{array}$} & $\mathrm{CT}(n=17)$ & $5.49 \pm 7.33$ & $18.69 \pm 17.19$ & $40.50 \pm 24.09$ & $51.4 \pm 24.0$ & 9.241 & $0.003^{\star}$ \\
\hline & $\Pi(n=130)$ & $9.71 \pm 11.76$ & $31.29 \pm 19.91$ & $53.91 \pm 20.80$ & $68.8 \pm 20.77$ & & \\
\hline
\end{tabular}

*Statistically significant difference between the groups $(p<0.05)$.

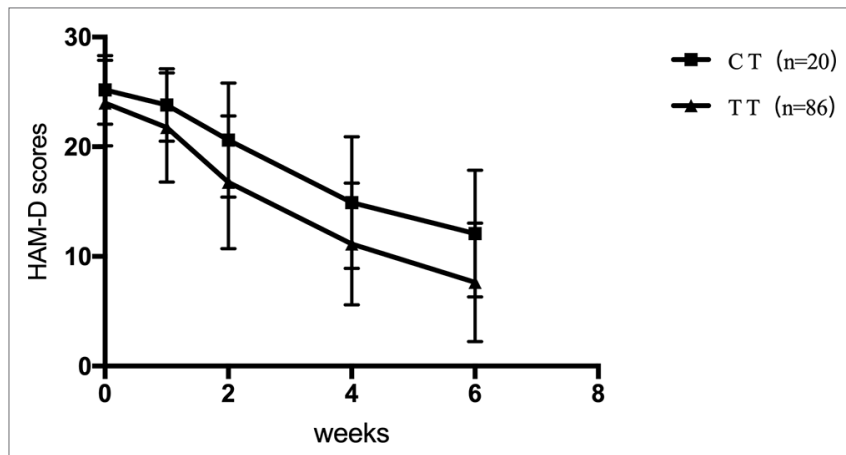

FIGURE 2 | HAM-D scores at the first, second, fourth, and sixth week (Rs2032583).
The study by Sarginson et al. (2010) showed that carriers of the $\mathrm{C}$ allele remitted faster than those with the TT genotype in the rs2032583 among paroxetine-treated patients and support the findings of Uhr et al. (2002) who found that rs2032583 genetic variants affected efficacy in patients of various ages treated with paroxetine and other $A B C B 1$ substrates (Uhr et al., 2008; Sarginson et al., 2010). By contrast, the two previous results are inconsistent with our present results. For rs2032583, we found that TT genotype has lower HAM-D17 scores than those of CT genotype and higher in decreased score and reducing score rate than those of CT genotype. This finding suggested that the TT genotype of rs 2032583 is likely to be a predictive factor of better treatment response to SNRIs. 
TABLE 8 | Rs2235040 and response to antidepressants.

\begin{tabular}{|c|c|c|c|c|c|c|c|}
\hline & & 1 week & 2 weeks & 4 weeks & 6 weeks & $\mathbf{F}$ & $p$ \\
\hline \multirow[t]{2}{*}{ Decreased score } & $\mathrm{AG}(n=20)$ & $1.45 \pm 1.76$ & $4.70 \pm 4.07$ & $10.75 \pm 6.02$ & $13.60 \pm 6.06$ & 4.288 & $0.041^{\star}$ \\
\hline & $\mathrm{GG}(n=86)$ & $2.22 \pm 2.68$ & $7.30 \pm 4.64$ & $12.76 \pm 5.41$ & $16.24 \pm 5.47$ & & \\
\hline \multirow{2}{*}{$\begin{array}{l}\text { Reducing score } \\
\text { rate }(\%)\end{array}$} & $\mathrm{AG}(n=20)$ & $5.74 \pm 7.21$ & $19.19 \pm 17.07$ & $42.75 \pm 23.17$ & $53.9 \pm 22.57$ & 6.64 & $0.011^{\star}$ \\
\hline & $\mathrm{GG}(n=86)$ & $9.65 \pm 11.80$ & $31.18 \pm 20.00$ & $53.39 \pm 21.33$ & $68.22 \pm 21.56$ & & \\
\hline
\end{tabular}

*Statistically significant difference between the groups $(p<0.05)$.

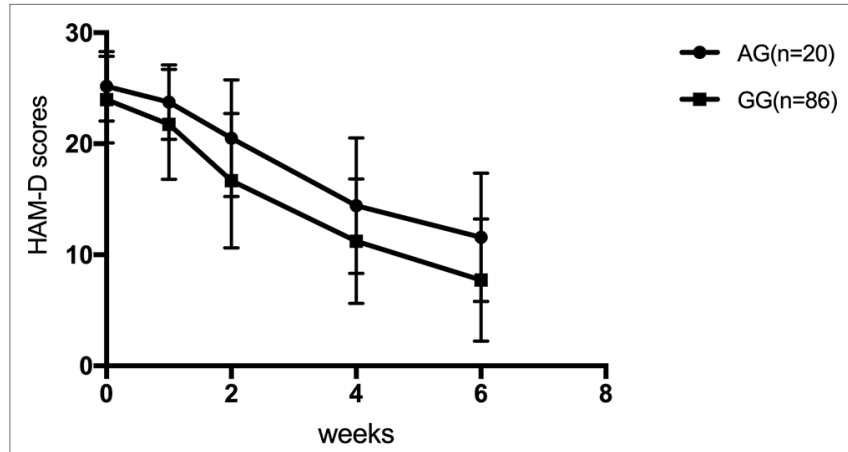

FIGURE 3 | HAM-D scores at the first, second, fourth, and sixth week (Rs2235040).

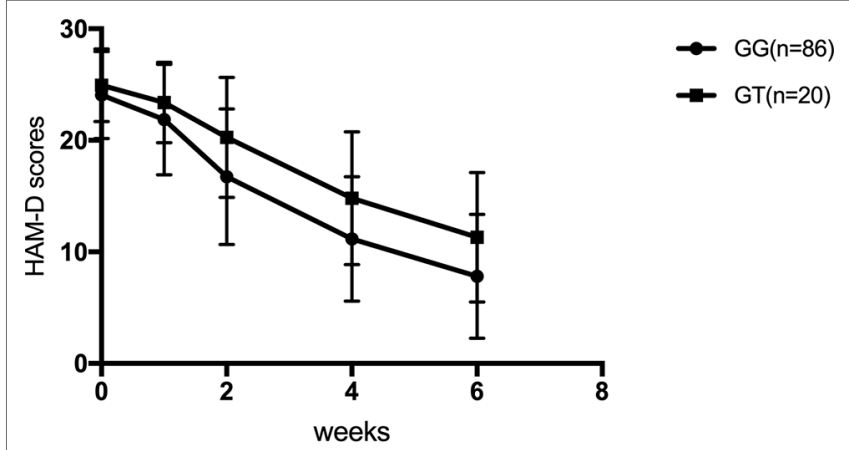

FIGURE 4 | HAM-D scores at the first, second, fourth, and sixth week (Rs2235015).

TABLE 9 | Rs2235015 and response to antidepressants.

\begin{tabular}{|c|c|c|c|c|c|c|c|}
\hline & & 1 week & 2 weeks & 4 weeks & 6 weeks & $\mathbf{F}$ & $p$ \\
\hline \multirow[t]{2}{*}{ Decreased score } & $\mathrm{GG}(n=130)$ & $2.20 \pm 2.67$ & $7.30 \pm 4.64$ & $12.90 \pm 5.28$ & $16.23 \pm 5.42$ & 4.93 & $0.029^{*}$ \\
\hline & $\mathrm{GT}(n=17)$ & $1.55 \pm 1.85$ & $4.70 \pm 4.08$ & $10.15 \pm 6.25$ & $13.65 \pm 6.29$ & & \\
\hline \multirow{2}{*}{$\begin{array}{l}\text { Reducing score } \\
\text { rate }(\%)\end{array}$} & $\mathrm{GG}(n=130)$ & $9.53 \pm 11.75$ & $31.12 \pm 20.0$ & $53.96 \pm 20.86$ & $68.1 \pm 21.32$ & 7.151 & $0.009^{*}$ \\
\hline & $\mathrm{GT}(n=17)$ & $6.27 \pm 7.82$ & $19.44 \pm 17.28$ & $40.31 \pm 23.73$ & $54.4 \pm 23.90$ & & \\
\hline
\end{tabular}

*Statistically significant difference between the groups $(p<0.05)$.

Whether the locus mutation manipulates the coding region of P-protein conformation remains to be further basic research. The rs2032583 locus mutation might change the dimensional conformation of P-gp by allowing entry of drugs and toxic substances into the brain simultaneously to exacerbate the symptoms. In addition, the locus mutation changes P-gp conformation and then stops the SNRIs into the brain but does not affect SSRI substrate. Furthermore, locus mutation may not change the conformation of P-gp. The positive results of SNRIs may be attributed to the small sample size, thereby causing false-positive results in the study. Foreign studies may have different results because of various factors such as race, region, environment, and diet.

Several limitations of the present study should be acknowledged. First, we did not distinguish the first and recurrence of depressive patients joining the patients' group. Regression analysis determines the total course of the disease and whether they accepted treatment; however, previous treatment had some influence on the overall response rate. Hence, the present study can only obtain a trend about differences. Second, the present study only selected the drugs that have been identified as substrates of P-gp. Future studies should include no-P-gp substrates such as mirtazapine. Third, genetic effect is slight because of the small sample size. A large sample size is needed to improve the power of the test. Fourth, many receptors are involved to determine the effect of antidepressant drugs; hence, a combination of gene should be considered. Larger and more homogenous samples will be included in our future research to improve the statistical power. Because there may be a delayed response to symptom relief, 6 weeks of treatment may not be sufficient to fully demonstrate the relationship between $A B C B 1$ gene and clinical response, and we consider extending the duration of efficacy observation in future studies.

\section{ETHICS STATEMENT}

The study protocol was approved by the Medical Ethics Committee of Second Xiangya Hospital, Central South University. Written informed consent was obtained from each patient after the study was explained.

\section{AUTHOR CONTRIBUTIONS}

$\mathrm{X}-\mathrm{XS}$ and YQ contributed equally to this work, mainly responsible for essay writing and conducting the study. W-WX mainly participated in conducting the study. YY assisted the study. R-RW, H-SW and L-HL contributed to guide of conducting the study and essay writing. 


\section{FUNDING}

This research was supported by National Natural Science Foundation of China (grant no. 81501163), National Natural

\section{REFERENCES}

Ameyaw, M., Regateiro, F., Li, T., Liu, X., Tariq, M., Mobarek, A., et al. (2001). MDR1 pharmacogenetics: frequency of the C3435T mutation in exon 26 is significantly influenced by ethnicity. Pharmacogenetics 11 (3), 217-221. doi: 10.1097/00008571-200104000-00005

de Klerk, O. L., Nolte, I. M., Bet, P. M., Bosker, F. J., Snieder, H., Den Boer, J. A., et al. (2013). ABCB1 gene variants influence tolerance to selective serotonin reuptake inhibitors in a large sample of Dutch cases with major depressive disorder. Pharmacogenomics J. 13 (4), 349-353. doi: 10.1038/tpj.2012.16

Dong, C., Wong, M. L., and Licinio, J. (2009). Sequence variations of ABCB1, SLC6A2, SLC6A3, SLC6A4, CREB1, CRHR1 and NTRK2: association with major depression and antidepressant response in Mexican-Americans. Mol. Psychiatry 14 (12), 1105-1118. doi: 10.1038/mp.2009.92

Kato, M., Fukuda, T., Serretti, A., Wakeno, M., Okugawa, G., Ikenaga, Y., et al. (2008). ABCB1 (MDR1)gene polymorphisms are associated with the clinical response to paroxetine in patients with major depressive disorder. Prog. Neuropsychopharmacol. Biol. Psychiatry 15 (32), 398-404. doi: 10.1016/j. pnpbp.2007.09.003

Lin, K. M., Chiu, Y. F., Tsai, I. J., Chen, C. H., Shen, W. W., Liu, S. C., et al. (2011). ABCB1 gene polymorphisms are associated with the severity of major depressive disorder and its response to escitalopram treatment. Pharmacogenet. Genomics 21 (4), 163-170. doi: 10.1097/FPC.0b013e32833db216

Menu, P., Gressier, F., Verstuyft, C., Hardy, P., Becquemont, L., and Corruble, E. (2010). Antidepressants and ABCB1 gene C3435T functional polymorphism: a naturalistic study. Neuropsychobiology 62 (3), 193-197. doi: 10.1159/000319361

Mihaljevic Peles, A., Bozina, N., Saqud, M., and Roinic Kuzman, M. (2008). Lovric M. MDR1 gene polymorphism: therapeutic response to paroxetine among patients with major depression. Prog. Neuropsychopharmacol. Biol. Psychiatry 32 (6), 1439-1444. doi: 10.1016/j.pnpbp.2008.03.018

Nikisch, G., Eap, C. B., and Baumann, P. (2008). Citalopram enantiomers in plasma and cerebrospinal fluid of ABCB1 genotyped depressive patients and clinical response: A pilot study. Pharmacol, Res. 58 (5-6), 344-347. doi: 10.1016/j.phrs.2008.09.010

Peters, E. J., Slager, S. L., Kraft, J. B., Jenkins, G. D., Reinalda, M. S., McGrath, P. J., et al. (2008). Pharmacokinetic genes do not influence response or tolerance to citalopram in the STAR ${ }^{\star}$ D sample. PLoS One 3 (4), e1872. doi: 10.1371/journal. pone.0001872

Rosenhagen, M. C., and Uhr, M. (2011). The clinical impact of ABCB1 polymorphisms on the treatment of psychiatric diseases. Curr. Pharm. Des. 17 (26), 2843-2851. doi: 10.2174/138161211797440140
Science Foundation of China (grant no. 81270019), National R\&D Special Fund for Health Profession (grant no. 201002003), and National Science and Technology Major Projects for "Major New Drugs Innovation and Development" (2012ZX09303014-001).

Sarginson, J. E., Lazzeroni, L. C., Ryan, H. S., Ershoff, B. D., Schatzberg, A. F., and Murphy, G. M., Jr. (2010). ABCB1 (MDR1) polymorphisms and antidepressant response in geriatric depression. Pharmacogenet. Genomics 20 (8), 467-775. doi: 10.1097/FPC.0b013e32833b593a

Singh, A. B., Bousman, C. A., Ng, C. H., Byron, K., and Berk, M. (2012). ABCB1 polymorphism predicts escitalopram dose needed for remission in major depression. Transl. Psychiatry 2, e198. doi: 10.1038/tp.2012.115

Uhr, M., Grauer, M. T., Yassouridis, A., and Ebinqer, M. (2007). Blood-brain barrier penetration and pharmacokinetics of amitriptyline and its metabolites in p-glycoprotein (abcblab) knock-out mice and controls. J. Psychiatr. Res. 41 (1-2), 179-188. doi: 10.1016/j.jpsychires.2005.10.005

Uhr, M., Grauer, M. T., and Holsboer, F. (2003). Differential enhancement of antidepressantpenetration into the brain in mice with abcblab (mdrlab) P-glycoproteingene disruption. Biol. Psychiatry 54 (8), 840-846. doi: 10.1016/ S0006-3223(03)00074-X

Uhr, M., Holsboer, F., and Müller, M. B. (2002). Penetration of endogenous steroid hormones corticosterone, cortisol, aldosterone and progesterone into the brain is enhanced in mice deficient for both mdrla and mdrlb P-glycoproteins. J. Neuroendocrinol. 14, 753-759. doi: 10.1046/j.1365-2826.2002.00836.x

Uhr, M., Steckler, T., Yassouridis, A., and Holsboer, F. (2000). Penetration of amitriptyline, but not of fluoxetine, into brain is enhanced in mice with blood-brain barrier deficiency due to mdrla P-glycoprotein gene disruption. Neuropsychopharmacology 22, 380-387. doi: 10.1016/S0893-133X(99)00095-0

Uhr, M., Tontsch, A., Namendorf, C., Ripke, S., Lucae, S., Ising, M., et al. (2008). Polymorphisms in the drug transporter gene $\mathrm{ABCB} 1$ predictantidepressant treatment response in depression. Neuron 57 (2), 203-209. doi: 10.1016/j. neuron.2007.11.017

Weizman, S., Gonda, X., Dome, P., and Faludi, G. (2012). Pharmacogenetics of antidepressive drugs: a way towards personalized treatment of major depressive disorder. Neuropsychopharmacol. Hung. 14 (2), 87-101. doi: 10.5706/nph201206002

Conflict of Interest Statement: The authors declare that the research was conducted in the absence of any commercial or financial relationships that could be construed as a potential conflict of interest.

Copyright (c) 2019 Shan, Qiu, Xie, Wu, Yu, Wu and Li. This is an open-access article distributed under the terms of the Creative Commons Attribution License (CC $B Y)$. The use, distribution or reproduction in other forums is permitted, provided the original author(s) and the copyright owner(s) are credited and that the original publication in this journal is cited, in accordance with accepted academic practice. No use, distribution or reproduction is permitted which does not comply with these terms. 